\title{
Comparison of Three Fungicide Spray Advisories for Lettuce Downy Mildew
}

\author{
B. M. Wu, K. V. Subbarao, Dept. of Plant Pathology, University of California, Davis, U.S. Agricultural Research \\ Station, 1636 E. Alisal St., Salinas, 93905; A. H. C. van Bruggen, Biological Farming Systems, Wageningen Uni- \\ versity and Research Centre, Marijkeweg 22, 6709 PG Wageningen, The Netherlands; and S. T. Koike, University \\ of California Cooperative Extension, Salinas, 93901
}

\begin{abstract}
Wu, B. M., Subbarao, K. V., van Bruggen, A. H. C., and Koike, S. T. 2001. Comparison of three fungicide spray advisories for lettuce downy mildew. Plant Dis. 85:895-900.

Lettuce growers in coastal California have relied mainly on protective fungicide sprays to control downy mildew. Thus, timing of sprays before infection is critical for optimal results. A leafwetness-driven, infection-based advisory system, previously developed, did not always perform satisfactorily. In this study, the advisory system was modified by incorporating a pathogen survival component (system 1) or both survival and sporulation components (system 2). These systems were then evaluated in commercial lettuce fields in coastal California during 19961998. Three or four treatments were carried out in each field: (i) no spray; (ii) sprays as scheduled by the growers; (iii) sprays following modified system 1; and (iv) sprays following the original advisory system (1996) or modified system 2 (1998). Downy mildew incidence was evaluated every 2 to 9 days. In fields with drip irrigation, the number of fungicide applications was reduced by one or two regardless of the advisory system used compared to the grower's calendarbased schedule, although one unnecessary spray was recommended in 1996 at Soledad and 1997 at Salinas. Under all three systems, disease levels were low (incidence $<25 \%$ and about 1 lesion per plant) for fields with drip irrigation, but not for fields with sprinklers (incidence up to $100 \%$ and 5 to 10 lesions per plant). For the first time, we established that survival and sporulation components are not needed for a lettuce downy mildew forecasting system. Instead, a threshold with a shorter period of morning leaf wetness and high temperatures were found to have potential for improving forecasting efficiency.
\end{abstract}

Additional keywords: Bremia lactucae, weather

Lettuce (Lactuca sativa L.) ranks second in total production among all vegetables in the United States, surpassed only by tomato. Of the 113,360 hectares of lettuce planted annually in the United States, about 81,000 ha $(71 \%)$ were planted in California and about 28,500 ha $(25 \%)$ in Arizona in 1997 (2).

Downy mildew caused by Bremia lactucae Regel is one of the most important lettuce diseases in California, and most of the fungicides (about $90 \%$ by weight) on lettuce are applied to control this disease. Because cultivars currently grown in California lack durable resistance against this disease (5), and because insensitivity to metalaxyl (the only eradicant fungicide registered for this disease in California) is prevalent among isolates of the pathogen $(5,15)$, lettuce growers commonly apply multiple calendar-based sprays of protective fungicides for downy mildew control (9).

Corresponding author: B. M. Wu

E-mail: bmwu@ucdavis.edu

Accepted for publication 24 April 2001

Publication no. D-2001-0611-02R

(C) 2001 The American Phytopathological Society
For instance, in 1996, 127,500 kg (applied to 80,200 ha) of maneb (contact), and $68,270 \mathrm{~kg}$ (on $27,950 \mathrm{ha}$ ) of fosetyl-Al (local systemic) and only $2,400 \mathrm{~kg}$ (on 9,300 ha) of metalaxyl were applied on lettuce against downy mildew in California (1).

Most of these fungicide applications are not necessary when weather conditions are not favorable for this disease (9). However, fungicide application is justified when weather conditions are highly conducive to lettuce downy mildew. Because of the large-scale lettuce production, fungicide spray advisory systems have great potential to reduce the total costs of lettuce production in California, even if they can reduce only slightly the number of fungicide applications on a crop. It was estimated that saving 1 application on $37.5 \%$ of lettuce acreage would save the growers in Monterey County $\$ 374,220$ to $\$ 425,520$ within the first year (Ed Kurtz, California Lettuce Research Board, personal communication). Thus, efforts have been made to develop fungicide spray advisory systems against lettuce downy mildew with the twin objectives of achieving a reduction in fungicide applications and improving disease control.

The secondary spread of the disease in the field results exclusively from infections by airborne sporangia. Sporulation of $B$. lactucae occurs during night when humidity is high and wind speed is low $(16,18)$, and the release of $B$. lactucae sporangia, triggered by the onset of light, coincides with decreased humidity and increased temperature $(3,14,17)$. Spore release begins at sunrise, and sporangium density reaches its peak between 10:00 a.m. and 12:00 noon $(3,14)$. The percentage of germination of $B$. lactucae sporangia at optimal temperature $\left(10\right.$ to $\left.15^{\circ} \mathrm{C}\right)$ increases rapidly from $<20 \%$ to around $60 \%$ when leaf wetness duration (LWD) increases from $2 \mathrm{~h}$ to $4 \mathrm{~h}$ (10). Sporangia deposited on lettuce leaves can germinate and infect lettuce within $3 \mathrm{~h}$ if leaf wetness is present $(6,10,18)$. Germination of $\mathrm{B}$. lactucae is also affected by temperature. When LWD ( $\geq 4 \mathrm{~h})$ is satisfied, the percentage of germinated sporangia decreases from about $60 \%$ to $<20 \%$ when temperature increases from $20^{\circ} \mathrm{C}$ to $25^{\circ} \mathrm{C}$, and is almost zero at $30^{\circ} \mathrm{C}(10)$. The latent period of lettuce downy mildew depends strongly on mean temperature when it is constant, but the effect of fluctuating temperature on the latent period is smaller (12). Epidemiological studies conducted in commercial lettuce fields in coastal California showed that prolonged morning LWD (4.2 h vs. 1.9 h) after Pacific Standard Time (PST) 6:00 was critical for infection of lettuce by downy mildew (13). Based on these results, a fungicide spray advisory was developed for lettuce downy mildew in California (9-14). The advisory system stated that fungicides should be applied if morning LWD persists for at least $4 \mathrm{~h}$ after spore release (assumed to start at 6:00 PST) and no fungicide has been applied during the past 7 days (9). A dew simulation model was used to predict morning LWD with weather forecasts as inputs of the model (7-9,11). Results of small-plot experiments and large-scale studies in commercial fields demonstrated that the total number of fungicide applications could be significantly reduced if sprays were applied according to this advisory system compared with growers' calendar-based spray schedules (9).

When weather conditions were highly conducive to downy mildew development, however, the advisory system sometimes did not recommend adequate fungicide applications, and satisfactory disease control was not achieved (9). The high disease 
levels observed, despite fungicide applications according to the advisory system, suggested the possibility that infection occurred on days with $<4 \mathrm{~h}$ morning LWD from 6:00 PST. One possible explanation for infection with $<4 \mathrm{~h} \mathrm{LWD}$ is that sporangia released in the morning may survive a dry morning and afternoon, and cause infection during the following night when leaf wetness returns. Although germinability and infectivity of B. lactucae sporangia after deposition on lettuce leaves declines more rapidly at $31^{\circ} \mathrm{C}$ than at $23^{\circ} \mathrm{C}$, considerable numbers of sporangia remain viable after exposure to $31^{\circ} \mathrm{C}$ for $8 \mathrm{~h}$ or longer $(20,21)$. Temperature may not be a critical factor under natural conditions on the central coast of California because hourly averages of temperature seldom exceed $31^{\circ} \mathrm{C}$ in this area. Relative humidity $(\mathrm{RH})$ was found to play less of a role in survival than temperature $(20,21)$. Solar radiation (mainly its UV-B component) was the dominant factor affecting survival of $B$. lactucae sporangia through a day $(19,20)$. In the Salinas Valley during summer months, B. lactucae sporangia can survive through a day only under a heavy cloud cover that reduces radiation to $1 / 4$ or less of the normal level on a clear day $(19,20)$.

The advisory system developed in 1995 sometimes recommended more fungicide applications than necessary when disease pressure was very low, and these low disease levels were assumed to be due to unavailability of inoculum on days with prolonged morning LWD (9). It was found that $\mathrm{B}$. lactucae rarely produced sporangia when $\mathrm{RH}$ was lower than $80 \%$ or wind speed was higher than $0.5 \mathrm{~m} \mathrm{~s}-1$ during the night (16).
The objectives of this study were to investigate improvement of the infectionbased model by incorporating the results of survival and sporulation studies into the downy mildew advisory system, and to test the modified system for downy mildew management in commercial lettuce fields.

\section{MATERIALS AND METHODS}

Modification of the previous system. In 1996, the original fungicide spray advisory system (OS) (9) was first modified to take into account infections at night caused by sporangia which survived through a day, in addition to the infections facilitated by prolonged morning LWD persisting to at least 10:00 PST, which is $4 \mathrm{~h}$ LWD from 6:00 PST (modified system \#1, MS1). In 1998, the system was further modified by adding a new component for sporulation of the pathogen (modified system \#2, MS2).

The following thresholds were used to predict downy mildew infection in the original system and the two modified systems. In OS, infection was predicted if morning LWD was measured or predicted to last until at least 10:00 PST (9).

In MS1, infection was predicted if OS predicted infection, or if weather conditions during daytime (11:00-20:00 PST) were suitable for the survival of sporangia. It was assumed that conditions were always conducive to infection at night. Sporangia would be predicted to survive one day if periods with air temperature higher than $30^{\circ} \mathrm{C}$ or solar radiation above $0.3 \mathrm{kWm}^{-2}$ did not last longer than $3 \mathrm{~h}$ during the day (19-21).

In MS2, infection was predicted only if active inoculum was available and weather conditions were suitable for infection. Active inoculum was considered available only

Table 1. Evaluation of forecasts of prolonged morning leaf wetness duration (LWD) ${ }^{\mathrm{a}}$ based on a dew simulation model with weather forecasts ${ }^{\mathrm{b}}$ as inputs during four trials in lettuce fields in coastal California

\begin{tabular}{lccccc}
\hline & & \multicolumn{3}{c}{ Days with forecast/measured prolonged $\mathbf{L W D}^{\mathbf{a}}$} \\
\cline { 3 - 6 } Year, location & Duration (days) & $\mathbf{N}^{\mathbf{c}} / \mathbf{N}^{\mathbf{d}}$ & $\mathbf{Y} / \mathbf{Y}$ & $\mathbf{N} / \mathbf{Y}$ & $\mathbf{Y} / \mathbf{N}$ \\
\hline 1996, Soledad & 31 & 29 & 0 & 0 & 2 \\
1997, Salinas & 34 & 28 & 0 & 0 & 1 \\
1998, Castroville & 30 & 27 & 0 & 3 & 0 \\
1998, Guadalupe & 29 & 23 & 0 & 6 & 0 \\
Total & 124 & 107 & 0 & 14 & 3 \\
\hline
\end{tabular}

a Leaf wetness persisting from 6:00 to at least 10:00 PST.

b Provided by SkyBit, Inc.

${ }^{c}$ Days when prolonged LWD was $(\mathrm{Y})$, or was not forecast $(\mathrm{N})$.

${ }^{\mathrm{d}}$ Days when prolonged LWD was (Y), or was not measured $(\mathrm{N})$. when weather conditions during the previous night were suitable for sporulation of $B$. lactucae. This required a 4-h or longer night period with $\mathrm{RH}>80 \%$ and wind speed $<0.5$ $\mathrm{m} \mathrm{s}^{-1}$ within the lettuce canopy (equivalent to $2.2 \mathrm{~m} \mathrm{~s}^{-1}$ and $3 \mathrm{~m} \mathrm{~s}^{-1}$ at heights of 1.5 and 3.0 $\mathrm{m}$ above ground level, respectively) (16). The infection-conducive weather conditions in MS2 were the same as in MS1.

Forecasts and measurements of weather and leaf wetness. High-resolution weather forecasts for the next $36 \mathrm{~h}$ were obtained daily via e-mail from SkyBit, Inc. The forecasts provided 3-hourly predictions of air temperature, $\mathrm{RH}$, leaf wetness, wind direction, wind speed, cloud cover, and solar radiation, and 6-hourly predictions of total precipitation and precipitation probability.

Forecast values of air temperature, $\mathrm{RH}$, cloud cover, and wind speed were interpolated into hourly data, then input into a dew simulation model (11) to generate daily predictions of morning LWD.

The observed leaf wetness and other weather data were recorded with a datalogger (CR 21X, Campbell Scientific Inc., Logan, UT), which was set up in commercial lettuce fields after thinning. Air temperature and RH were measured with temperature-RH probes (model 207, Campbell Scientific Inc.) in the lettuce canopy at a height of $0.2 \mathrm{~m}$ above ground. Leaf wetness was measured with leaf wetness sensors (Model 237, Campbell Scientific Inc.) placed within the lettuce canopy at $0.2 \mathrm{~m}$ above ground with an angle of $45^{\circ}$ facing north. Solar radiation, precipitation, and wind speed were measured at a height of $1.5 \mathrm{~m}$ above ground level with pyranometers (model LI200S, LI-COR, Lincoln, $\mathrm{NE}$ ), tipping bucket rain gauges (Model TE525, Texas Electronics, Dallas, TX) and anemometers (model 03101-5, R. M. Young Company, Traverse City, MI), respectively. All data were measured at 5-min intervals, and hourly means or totals for precipitation were stored. The hourly measured data were transferred to a computer daily via a cellular phone communication system.

Field experiments and simulation. During 1996, 1997, and 1998, one or two of the advisory systems were compared with regular spray schedules used by growers in five commercial fields in coastal California. The same weather data were also used to run simulations of advisory systems not included in field experiments.

Table 2. Errors in forecast termination time of morning leaf wetness duration (LWD) based on the dew simulation model with weather forecasts (SkyBit, Inc.) as inputs during four field trials in coastal California

\begin{tabular}{|c|c|c|c|c|c|c|c|}
\hline Year, location & $\begin{array}{c}\text { Duration } \\
\text { (days) }\end{array}$ & Days with error $=0 \mathrm{~h}$ & Days with error $=1 \mathrm{~h}$ & Days with error $=2 \mathrm{~h}$ & Days with error $>2 \mathrm{~h}$ & Bias (h) & Standard error \\
\hline 1998, Guadalupe & 29 & 4 & 4 & 8 & 13 & $2.41 \mathrm{a}$ & 4.25 \\
\hline 1998, Castroville & 30 & 8 & 13 & 2 & 7 & $0.67 \mathrm{~b}$ & 3.38 \\
\hline 1997, Salinas & 34 & 7 & 10 & 12 & 5 & $0.38 \mathrm{~b}$ & 3.61 \\
\hline 1996, Soledad & 31 & 5 & 11 & 11 & 4 & $-1.39 \mathrm{c}^{\mathrm{a}}$ & 2.33 \\
\hline Total & 124 & 24 & 38 & 33 & 29 & & \\
\hline
\end{tabular}

${ }^{a}$ Means followed by different letters are significantly different according to the Duncan's multiple range test $(\mathrm{P} \leq 0.05)$. 
Randomized complete block designs were used for all field experiments that included three or four treatments replicated three times each. Each plot was eight or twelve beds wide $(1 \mathrm{~m}$ between bed centers) and $70 \mathrm{~m}$ long with 2 rows of lettuce on each bed ( $30 \mathrm{~cm}$ between lettuce plants). The treatments were: A: maneb applied (1.8 $\mathrm{kg}$ active ingredient per hectare) if MS1 predicted infection and no spray had been applied during the past 7 days (1996-1998); B: maneb applied if OS (1996) or MS2 (1998) predicted infection and no maneb had been sprayed during the past 7 days; C: maneb applied according to the grower's schedule (GS); D: no maneb applied (CK). Surface drip irrigation systems were used in all experimental fields except in trial 3 , in which sprinkler irrigation was used.

Observed weather and leaf wetness data, together with forecast weather and predicted leaf wetness, were input daily into the systems (OS, MS1, and MS2) to predict infection. Subsequently, fungicide application recommendations were made based on whether infection had been predicted and whether fungicide had been applied during the past 7 days.

Downy mildew incidence was examined every 2 to 9 days. Each time, 100 lettuce plants were selected in each plot by picking one plant every $2 \mathrm{~m}$ in a diagonal pass through the plot. The selected plants were evaluated for the presence or absence of downy mildew.

Data analyses. The leaf wetness forecasts (only for the fields with drip irrigation) were first analyzed to determine the accuracy of classifying days with or without prolonged morning LWD (lasting until 10:00 PST or later, i.e., 4 h). All days were divided into four groups: days when prolonged LWD was predicted and measured (correct); days when prolonged LWD was neither predicted nor observed (correct); days when prolonged LWD was measured but not predicted (type I errors); and days when prolonged LWD was predicted but not measured (type II errors). The time of predicted termination of morning leaf wetness (LW) was then compared with the time of morning LW termination measured in the field, and the difference was calculated for each day. The numbers of days with $0 \mathrm{~h}, 1$ $\mathrm{h}, 2 \mathrm{~h}$, and larger errors in forecasts, as well as the mean errors (bias) and standard errors of the forecasts, were then calculated for each experiment. Duncan's multiple range test was used to differentiate the mean errors among the trials.

Forecast and measured weather variables influencing the survival of $B$. lactucae sporangia were assigned to four groups based on the assumptions described previously: (i) both forecast and observed weather allowed survival of $B$. lactucae sporangia; (ii) neither forecast nor observed weather allowed survival; (iii) forecast weather did not allow survival but measured weather did; and (iv) forecast weather allowed survival but measured weather did not. The numbers of days within each group were used to determine how well the forecasts predicted the weather conditions limiting the survival of B. lactucae sporangia. The same analysis was also carried out on weather variables affecting sporulation of B. lactucae.

To evaluate different disease control systems, the number of days with forecast infection and the total recommended sprays were calculated for each system. Subsequently, the infections predicted by each system were compared with the infections deduced from the disease progress curves. Observed downy mildew incidence was then plotted against time, and the days with a considerable increase in downy mildew incidence were identified. Three days (average latent period of this disease) occurring 7 to 9 days before an observed disease incidence increase were considered to be infection days $(12,13)$.

Finally, the disease incidence data observed on the same plots over the experimental periods were considered as repeated measurements on the same experimental units. A repeated measures analysis was conducted with the General Linear Models procedure (SAS Institute, Inc., Cary, NC) to determine the effects of treatments, assessment time, and their interaction. For the experiments with significant treatment effects, Duncan's multiple range test was

Table 3. Evaluation of weather forecasts used for prediction of sporulation and survival of $B$. lactuace during the summers of 1996 to 1998 in coastal California

\begin{tabular}{|c|c|c|c|c|c|c|c|c|c|}
\hline \multirow[b]{2}{*}{ Year, location } & \multirow[b]{2}{*}{ Irrigation } & \multicolumn{4}{|c|}{$\begin{array}{c}\text { Survival conducive days } \\
\text { (Forecast/measured) }\end{array}$} & \multicolumn{4}{|c|}{$\begin{array}{c}\text { Sporulation conducive days } \\
\text { (Forecast/measured) }\end{array}$} \\
\hline & & $\mathbf{N} / \mathbf{N}^{\mathrm{a}}$ & $\mathbf{Y} / \mathbf{Y}$ & $\mathbf{N} / \mathbf{Y}$ & $\mathbf{Y} / \mathbf{N}$ & $\mathbf{N} / \mathbf{N}^{b}$ & $\mathbf{Y} / \mathbf{Y}$ & N/Y & $\mathbf{Y} / \mathbf{N}$ \\
\hline 1996, Soledad & Drip & 31 & 0 & 0 & 0 & 1 & 25 & 3 & 2 \\
\hline 1997, Salinas & Drip & 34 & 0 & 0 & 0 & 1 & 24 & 6 & 3 \\
\hline 1997, Castroville & Sprinkler & 29 & 0 & 0 & 0 & 0 & 29 & 0 & 0 \\
\hline 1998, Castroville & Drip & 30 & 0 & 0 & 0 & 1 & 21 & 8 & 0 \\
\hline 1998, Guadalupe & Drip & 29 & 0 & 0 & 0 & 3 & 25 & 1 & 0 \\
\hline Total & & 153 & 0 & 0 & 0 & 6 & 124 & 18 & 5 \\
\hline
\end{tabular}

${ }^{a}$ Weather conditions for survival were $(\mathrm{Y})$ or were not $(\mathrm{N})$ forecast/were $(\mathrm{Y})$ or were not $(\mathrm{N})$ observed.

${ }^{b}$ Weather conditions for sporulation were $(\mathrm{Y})$ or were not $(\mathrm{N})$ forecast/were $(\mathrm{Y})$ or were not $(\mathrm{N})$ observed.

Table 4. Number of fungicide applications according to fungicide advisory systems and grower's schedule $^{\mathrm{a}}$

\begin{tabular}{|c|c|c|c|c|c|c|c|c|c|c|}
\hline \multirow[b]{2}{*}{ Year \& location } & \multicolumn{3}{|c|}{ Days with forecast infection } & \multicolumn{3}{|c|}{ Recommended sprays } & \multicolumn{4}{|c|}{ Actual sprays } \\
\hline & OS & MS1 & MS2 & OS & MS1 & MS2 & OS & MS1 & MS2 & $\overline{\text { GS }}$ \\
\hline 1996, Soledad & 2 & 2 & 2 & 1 & 1 & 1 & 1 & 1 & b & 2 \\
\hline 1997, Salinas & 6 & 6 & 6 & 1 & 1 & 1 & b & 1 & b & 3 \\
\hline 1997, Castroville & 11 & 11 & 11 & 3 & 3 & 3 & $0^{c}$ & $0^{c}$ & b & 3 \\
\hline 1998, Castroville & 3 & 3 & 3 & 1 & 1 & 1 & $\mathrm{~b}$ & 1 & 1 & 3 \\
\hline 1998, Guadalupe & 6 & 6 & 6 & 2 & 2 & 2 & $\mathrm{~b}$ & $1^{\mathrm{d}}$ & $1^{\mathrm{d}}$ & 3 \\
\hline Total & 28 & 28 & 28 & 8 & 8 & 8 & - & - & - & 14 \\
\hline
\end{tabular}

a $\mathrm{OS}=$ Original system, MS1 = modified system with survival, MS2 = modified system with survival and sporulation, GS = grower's schedule.

${ }^{\mathrm{b}}$ This treatment was not included in the trial.

${ }^{\mathrm{c}}$ Fungicide was not applied as recommended because the field was too wet after sprinkler irrigation.

d A recommended spray was skipped due to circumstances beyond our control. 
$55,27,10$, and $<5 \mathrm{~km}$, respectively. Multiple comparisons showed that the model tended to predict later termination time of morning LWD than measured in Soledad (in the central part of the Salinas Valley), but it tended to predict earlier termination time in Guadalupe. The forecasts in Salinas and Castroville had the least bias, and no significant difference was found between these two locations.

Because MS1 and MS2 also used forecasts of other weather variables in addition to leaf wetness, the forecast and measured weather variables used in the two systems were compared for all days during the five experiments (Table 3). The errors in weather forecasts did not influence the predicted survival of $B$. lactucae sporangia. Not a single day was forecast or measured to be suitable for survival of $B$. lactucae sporangia during the five experiments ac-
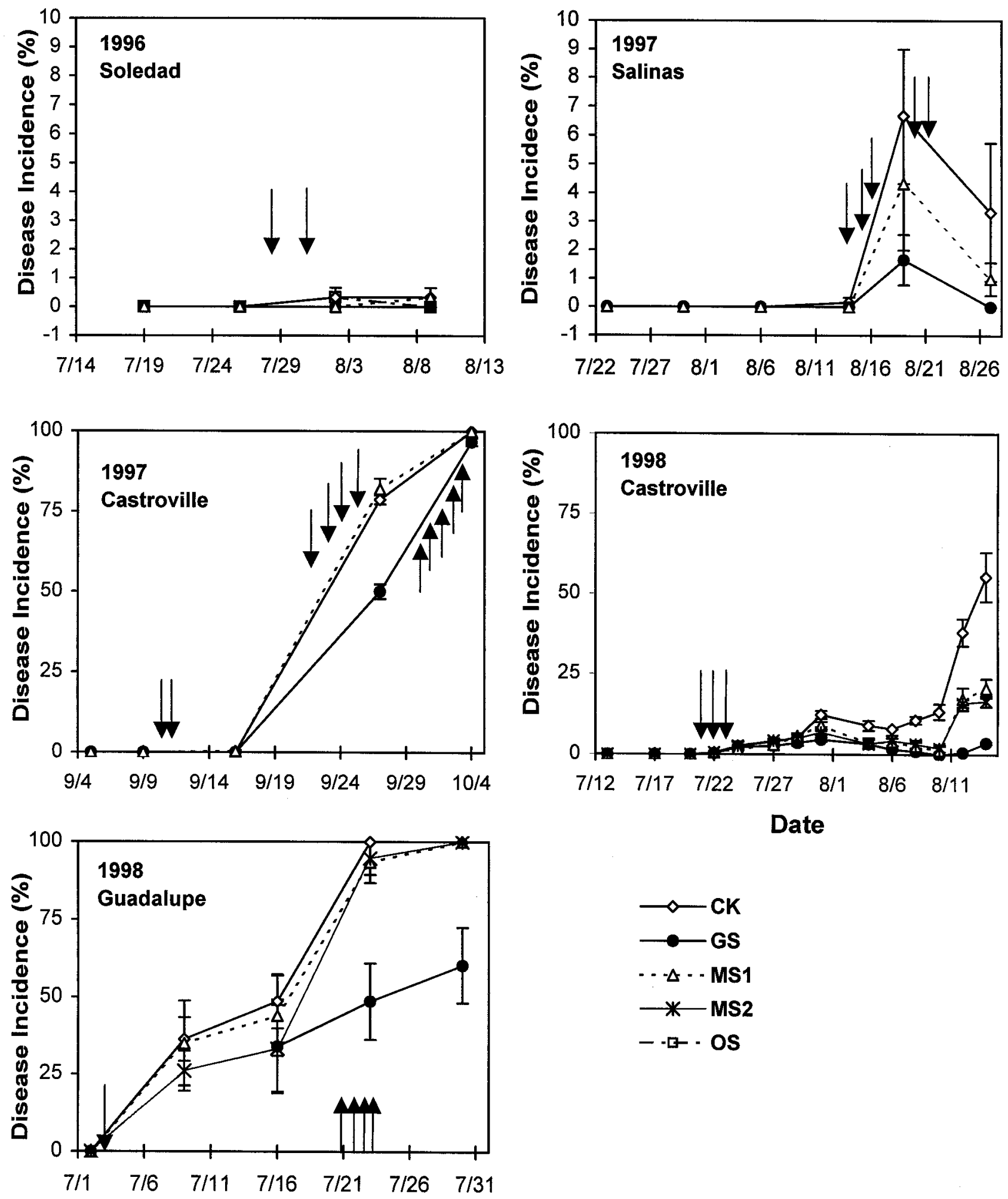

Fig. 1. Predicted infection days by three fungicide spray advisory systems against downy mildew (MS1, MS2, and OS, indicated by arrows) and observed disease incidence (lines and standard error bars) in plots with different treatments in five trials conducted in commercial lettuce fields (CK $=$ no fungicide was sprayed against lettuce downy mildew, GS = maneb was sprayed according to grower's schedule, OS = maneb was sprayed following the original fungicide spray advisory system, MS1 = maneb was applied following modified system 1, and MS2 = maneb applied according to modified system 2). 
cording to the conditions described previously. The percentages of type I errors (failure to predict sporulation-conducive weather conditions) and type II errors (erroneously predicted sporulation-conducive weather conditions) in forecasts of sporulation conditions were 12 and $3 \%$, respectively. The rate of correct forecasts was $85 \%$ (including $4 \%$ without sporulation and $81 \%$ with sporulation).

Evaluation of fungicide spray advisory systems. The infection predictions based on forecast and observed weather data were the same during the five experiments for all three systems. Although we added the limitation of sporulation conditions to MS2, days with predicted infection were not decreased because sporulation of B. lactucae was predicted for all the nights preceding the days with prolonged morning LWD $(\geq 10: 00$ PST). Therefore, all three systems recommended the same number of fungicide applications on exactly the same days (data not shown), resulting in the same number of sprays (Table 4). During the three summers, the systems recommended fewer fungicide sprays than the grower's schedule in four experiments. In one experiment in Castroville in which sprinkler irrigation was used and disease pressure was high, they recommended the same number of sprays as the grower's schedule. If fungicide had been applied according to any of the advisory systems, the total reduction of sprays for the five crops would have been 6 (43\% lower than grower's schedule) compared to the grower's schedule (with a total of 14 sprays).

Despite the large errors in forecasts of prolonged morning LWD, infections of lettuce downy mildew predicted by the three systems, OS, MS1, and MS2, explained most of the increases in disease incidence (Fig. 1A-E). For the five trials, all predicted infection days were within the possible infection periods deduced from disease incidence and latent period (13), although some infection days were possibly missed by each of the three systems. Consequently, increases in downy mildew incidence in plots following fungicide application recommendations were lower compared to plots without sprays.

Significant time effects were identified in four of the five trials by repeated measures analysis of variance (Table 5). This indicated that the disease progressed in these trials. In the trial at Soledad in 1996, no significant disease increase was observed; consequently, no significant treatment effect was detected. In the trial at Salinas in 1997, the time effect was less pronounced than in trials at Castroville in 1997 and 1998 , or at Guadalupe in 1998, although it was still significant. This was due to very low disease pressure, resulting in a lack of significant treatment effects. Different disease control systems have resulted in significant differences in disease progress during trials at Castroville in 1997 and
1998. In the trial at Guadalupe in 1998, significant differences were detected in the fourth and fifth weekly disease observations, although differences were not significant for the whole season. For all the three trials, the interaction effects of time and treatment were significant, because treatment effects could be observed only at later stages of disease development.

The multiple comparison showed that only the grower's schedule (GS) resulted in a reduction in disease development in comparison with the control (CK) in trials at Castroville in 1997 and at Guadalupe in 1998 (Table 6). In the trial at Castroville in 1998 , the fungicide spray advisory systems resulted in significantly less disease than the control treatment; however, they allowed slightly but significantly more disease than the grower's schedule.

\section{DISCUSSION}

The results of the five field experiments generally followed the same trends as observed in the seven trials by Scherm et al. (9). In trials at Soledad in 1996 and at Salinas in 1997, our systems recommended fewer sprays than the grower's schedule. However, on the basis of the observed disease levels, we should have been able to reduce the number of sprays even further because the disease incidence in control plots was very low $(0.3$ and $4 \%$, respectively). Scherm et al. (9) explained that the low disease level might have resulted from low levels of initial inoculum. Since lettuce is always grown nearby, variability in initial inoculum levels was addressed by adding a sporulation module to the system, but this did not improve performance.

In trials at Castroville and Guadalupe in 1998, the predicted infection days could not explain all the increases in downy mildew incidence. In the trial at Castroville, the systems identified three consecutive infection days, from 21 to 23 July 1998, and thus recommended one spray. However, another major increase in downy mildew incidence was also observed between 10 and $14 \mathrm{Au}$ gust 1998 without predicted infection. Thus, the systems apparently missed at least one infection day around 4 August. In the trial at Guadalupe, similarly, the systems might have missed some infection days between 9 and 16 July 1998, resulting in an increase of downy mildew incidence between 16 and 23 July. We observed LWD ending before 10:00 PST but after 9:00 PST on 1, 2, and 5 August at Castroville, and on 9 July at Guadalupe. A likely explanation for this is that $3 \mathrm{~h}$ LWD may be long enough for $B$. lactucae sporangia to germinate and infect lettuce when other conditions are highly conducive to downy mildew. Therefore, we advise changing the LWD threshold for infection to prolonged LWD until 9:00 PST (i.e., $3 \mathrm{~h} \mathrm{LWD)}$. This change is supported by germination and infection experiments and field studies on this disease $(6,10,13,18)$. Verhoeff $(18)$ found that $B$. lactucae sporangia could penetrate a lettuce leaf within $3 \mathrm{~h}$ after spore deposition under optimal conditions. Between 10 and $22^{\circ} \mathrm{C}$, entrance of the pathogen into the leaf could be prevented by spraying zineb within $3 \mathrm{~h}$ after inoculation, but not after $3 \mathrm{~h}$ (18). Scherm and van Bruggen (10) also observed that $B$. lactucae sporangia caused some infections in as short a time as $2 \mathrm{~h}$ LWD when temperature was optimal, although the percentage of infected leaf area was lower than with $4 \mathrm{~h}$ LWD. In field experiments, the average LWD for days identified as conducive to infection was $4 \mathrm{~h}$ after 6:00 PST (13). This meant that about half of the infection-conducive days had a

Table 5. Results of repeated measures analysis of variance on lettuce downy mildew incidence in five experiments to test the different advisory systems

\begin{tabular}{lcccccccc}
\hline \multirow{2}{*}{ Year \& location } & \multicolumn{2}{c}{ Treatment } & & \multicolumn{2}{c}{ Time } & & \multicolumn{2}{c}{ Treatment $\times$ Time } \\
\cline { 2 - 3 } & MSE $^{\mathbf{a}}$ & $\boldsymbol{P}>\boldsymbol{F}^{\mathbf{b}}$ & & MSE & $\boldsymbol{P}>\boldsymbol{F}$ & & MSE & $\boldsymbol{P}>\boldsymbol{F}$ \\
\hline 1996, Soledad & $<0.001$ & 0.487 & & $<0.001$ & 0.320 & $<0.001$ & 0.750 \\
1997, Salinas & $<0.001$ & 0.2366 & & 0.003 & $<0.001$ & $<0.001$ & 0.266 \\
1997, Castroville & 0.023 & $<0.001$ & & 2.02 & $<0.001$ & 0.018 & $<0.001$ \\
1998, Castroville & 0.069 & $<0.001$ & & 0.059 & $<0.001$ & 0.013 & $<0.001$ \\
1998, Guadalupe & 0.193 & 0.82 & & 1.747 & $<0.001$ & 0.034 & 0.006 \\
\hline
\end{tabular}

${ }^{a}$ Mean square error.

${ }^{\mathrm{b}}$ Probabilities associated with individual $F$ tests.

Table 6. Lettuce downy mildew incidence after different spray treatments at three locations in coastal California

\begin{tabular}{|c|c|c|c|c|c|}
\hline \multicolumn{2}{|c|}{1997 Castroville } & \multicolumn{2}{|c|}{1998 Castroville } & \multicolumn{2}{|c|}{1998 Guadalupe } \\
\hline Treatment $^{\mathrm{a}}$ & $\operatorname{Mean}^{b}(\%)$ & Treatment & Mean $(\%)$ & Treatment & Mean (\%) \\
\hline MS1 & $36.5 \mathrm{~A}$ & CK & $11.4 \mathrm{~A}$ & CK & $57 \mathrm{~A}$ \\
\hline CK & $35.7 \mathrm{~A}$ & MS1 & $5.0 \mathrm{~B}$ & MS1 & $54 \mathrm{~A}$ \\
\hline \multirow[t]{2}{*}{ GS } & $29.3 \mathrm{~B}$ & MS2 & $4.7 \mathrm{~B}$ & MS2 & $51 \mathrm{~A}$ \\
\hline & & GS & $1.7 \mathrm{C}$ & $1.7 \mathrm{C}$ & $36 \mathrm{~B}$ \\
\hline
\end{tabular}

${ }^{a}$ MS1 = Modified system 1; MS2 = modified system 2; GS = grower's schedule; CK = control.

b Means followed by different letters are significantly different according to the Duncan's multiple range test $(P \leq 0.05)$. 
morning LWD shorter than $4 \mathrm{~h}$ after 6:00 PST.

Another way to improve the advisory system would be to incorporate effects of temperature into the existing infection prediction model. It has been reported that lettuce downy mildew severity is lower during hot summers than during cool spring and fall seasons. It has also been observed that high temperatures affect germination and infection by B. lactucae sporangia (10). In the Salinas Valley, however, temperatures during morning LWD are almost always optimal $\left(10\right.$ to $\left.18^{\circ} \mathrm{C}\right)$ for germination and infection of the pathogen, thus, high temperature is unlikely to limit germination and infection of sporangia in commercial lettuce fields. The effects of high temperature on downy mildew epidemics require further investigation, although studies on downy mildew of lima bean showed that high temperature following infection arrested the disease (4).

Some obstacles for implementation of fungicide spray advisory systems in commercial fields also come from communication, practical difficulties, and response time required for preparing fungicide applications. One or more recommended sprays were skipped due to unmanageable conditions in both trials at Castroville 1997 and at Guadalupe in 1997. In the Castroville trial, none of the recommended sprays could be applied because the field was too wet to access after sprinkler irrigation. We therefore recommend avoiding sprinkler irrigation in areas with high downy mildew pressure. Growers especially should avoid using sprinkler irrigation in the morning. If growers are unable to do either, fungicides should be sprayed from aircraft immediately after sprinkler irrigation. In the Guadalupe trial, one recommended spray was skipped because spray applicators were unavailable during holidays. To solve problems caused by dates or a breakdown of communication, we advise providing some long-term or midterm predictions before actually triggering the short-term fungicide application actions. This would allow growers to make arrangements for potential sprays.
Another important factor that affects the effectiveness of disease control using our fungicide spray advisory system is the accuracy of predicting weather variables and leaf wetness duration. Since infection of lettuce by Bremia lactucae requires less than $4 \mathrm{~h}$ of LWD, an error in prediction of morning LWD could result in destructive epidemics of downy mildew. Errors in LWD predictions with the dew simulation model have been a major cause for inaccuracy of infection forecasts by our systems. Current weather forecasts and derived leaf wetness predictions are not accurate enough to be used in fungicide advisory systems. LWD and weather forecasts need to be improved before we can generate accurate disease forecasts.

\section{ACKNOWLEDGMENT}

We thank all the farmers who offered fields and cooperation, and SkyBit Inc. for providing weather forecasts. This research was supported by SmithLever IPM grants (96SL019 and 97SL001) to K. V. Subbarao and A. H. C van Bruggen, and by an USDA NRI grant (96-35313-3752) to A. H. C. van Bruggen, K. V. Subbarao, and R. W. Michelmore.

\section{LITERATURE CITED}

1. Anonymous. 1997. California Vegetable Chemical Use-1996. California Agriculture Statistics Service (CASS). Sacramento, CA. On-line, publication \#97172.

2. Anonymous. 1998. U. S. vegetable commodity rankings-1997-top ten states and United States based on production. USDA-National Agriculture Statistics Service (NASS). Online.

3. Fletcher, J. 1976. Bremia lactucae, oospores, sporangial dissemination and control. Ann. Appl. Biol. 84:294-298.

4. Hyre, R. A. 1964. High temperature following infection checks downy mildew of lima bean. Phytopathology 54:181-184.

5. Michelmore, R. W., and Ochoa, O. E. 1997. Lettuce Breeding. Pages 34-43 in: Annual Lettuce Research Report. Crop Year 1996. California Iceberg Lettuce Advisory Board, Salinas.

6. Powlesland, R. 1954. On the biology of Bremia lactucae. Trans. Br. Mycol. Soc. 37:362371.

7. Pedro, M. J., and Gillespie, T. J. 1982. Estimating dew duration I. Utilizing micrometeorological data. Agric. Meteorol. 25:283-296.

8. Pedro, M. J., and Gillespie, T. J. 1982. Estimating dew duration II. Utilizing standard weather station data. Agric. Meteorol. 25:297-310.

9. Scherm, H., Koike, S. T., Laemmlen, F. F., and van Bruggen, A. H. C. 1995. Field evaluation of fungicide spray advisories against lettuce downy mildew (Bremia lactucae) based on measured or forecast morning leaf wetness. Plant Dis. 79: 511-516.

10. Scherm, H., and van Bruggen, A. H. C. 1993. Response surface models for germination and infection of Bremia lactucae, the fungus causing downy mildew of lettuce. Ecol. Modelling 65: 281-296.

11. Scherm, H., and van Bruggen, A. H. C. 1993. Sensitivity of simulated dew duration to meteorological variations in different climatic regions of California. Agric. For. Meteorol. 66:229-245.

12. Scherm, H., and van Bruggen, A. H. C. 1994 Effects of fluctuating temperatures on the latent period of lettuce downy mildew (Bremia lactucae). Phytopathology 84: 853-859.

13. Scherm, H., and van Bruggen, A. H. C. 1994. Weather variables associated with infection of lettuce by downy mildew (Bremia lactucae) in coastal California. Phytopathology 84: 860865

14. Scherm, H., and van Bruggen, A. H. C. 1995. Concurrent spore release and infection of lettuce by Bremia lactucae during mornings with prolonged leaf wetness. Phytopathology 85: 552-555.

15. Schettini, T. M., Legg, E. J., and Michelmore, R. W. 1991. Insensitivity to metalaxyl in California populations of Bremia lactucae and resistance of California lettuce cultivars to downy mildew. Phytopathology 81: 64-70.

16. Su, H., van Bruggen, A. H. C., and Subbarao, K. V. 1998. Moving air and relative humidity affect sporulation of Bremia lactucae. (Abstr.) Phytopathology 88:S86.

17. Su, H., van Bruggen, A. H. C., and Subbarao, K. V. 2000. Spore release of Bremia lactucae on lettuce is affected by timing of light initiation and decrease in relative humidity. Phytopathology 90:67-71.

18. Verhoeff, K., 1960. On the parasitism of Bremia lactucae Regel on lettuce. Tijdschr. Planteziekten 66: 133-203.

19. Wu, B. M., Subbarao, K. V., and van Bruggen, A. H. C. 1998. Effects of solar radiation on survival of Bremia lactucae sporangia on lettuce leaves. (Abstr.) Phytopathology 88:S99.

20. Wu, B. M., Subbarao, K. V., and van Bruggen, A. H. C. 2000. Factors affecting the survival of Bremia lactucae sporangia deposited on lettuce leaves. Phytopathology 90:827-833

21. Wu, B. M., van Bruggen, A. H. C., and Subbarao, K. V. 1997. Effects of temperature and relative humidity on survival of Bremia lactucae sporangia on lettuce leaves. (Abstr.) Phytopathology 87: S104. 